\title{
The Da'wah Movement of Ulama Dayah (Analysis the Da'wah Movement of Têungkū Hasanoel Bashry)
}

\author{
Zulfikar $^{1}$, Saiful Bahri ${ }^{1}$, Muslem $^{1}$, Fatahillah $^{2}$, Amiruddin $^{2}$, Muhibuttibri $^{2}$ \\ ${ }^{1}$ Lecturer in Islamic Institute of Islam (IAI) Al-Aziziyah Samalanga Bireun Aceh, Indonesia \\ ${ }^{2}$ Students in Islamic Institute of Islam (IAI) Al-Aziziyah Samalanga Bireun Aceh, Indonesia \\ Email: fikarz78@gmail.com
}

\begin{abstract}
:
The purpose of this research is to find out about how the da'wah movement of Têngki Hasanoel Bashry one of the dayah scholars in conducting da'wah activities, and to find out the basis of the da'wah movement of Têungkü Hasanoel Bashry, where the da'wah movement can be said to be able to answer various problems and problems experienced by the people of Aceh at this time, especially religious issues. This type of research is a qualitative research using a character study that aims to provide answers to how the da'wah movement developed by dayah scholars. The results of this study illustrate how the missionary movement Têungkū Hasanoel Bashry, starting from establishing the Al-Aziziyah Islamic College in 2003, developing dayah economics, forming social organizations such as MUDI alumni ties and TASTAFI administrators, cooperating with the government and several countries, and had initiated the birth of a local political party Aceh Daulat Party (PDA) as a forum for entry into the legislative body for dayah graduates. The foundation of the da'wah movement of Têungkü Hasanoel Bashry is to hold fast to the Al-Qur'an and Hadith and Ijma 'of the previous scholars, so as to be able to answer the various problems faced by the people of Aceh at this time, starting from the problems of the Aqeedah, Sharia, and contemporary problems. The da'wah movement Teungku Hasanoel Hasano Bashry has been able to inspire the public to participate in various da'wah activities which are conveyed through discussion media, questions and answers, print media, electronic media and social media. So the da'wah that he delivered was liked by various groups of people, men and women, parents and also young people.

Keywords:

the Da'wah movement; Ulama Dayah
\end{abstract}

\section{Introduction}

So far, the da'wah delivered by the dayah scholars is still very limited in scope, only to certain communities and has not been able to answer various problems in the wider community. Then it is necessary to make a da'wah movement that can be reached by all levels of society, so that da'wah is not only specific anymore but is already general in nature.

One of the dayah scholars in Aceh who was still pro-active in carrying out the da'wah movement Têungkū Hasanoel Bashry. This can be seen from the deeds and movements of da'wah that he did was one proof that Têungkū Hasanoel Bashry was serious in developing da'wah in the present and also in the future. His da'wah movement was not only focused on one movement, but also various forms of movement that were adapted to your circumstances and needs. Of the many proselytizing movements, the most frequently used by Têungku Hasanoel Bashry is the da'wah movements in the form of recitation, discussion and question and answer. In addition, the da'wah movement also uses a variety of da'wah media, both print and electronic media. The target of preaching also includes all lines and circles of society. So it can be said for now, Têungkū Hasanoel Bashry is one of the Aceh dayah scholars who are highly committed in developing da'wah activities. 
Establishing the Islamic College of Religion (IAIA) which is now an Al-Aziziyah Islamic Institute (IAI) in the midst of the MUDI Dayah environment of the Samalanga Grand Mosque, which continues to grow from year to year, can be said as concrete evidence of the proactively and seriousness of Têungkū Hasanoel Bashry in carrying out the da'wah movement in this day and age. So that alumni produced by these educational institutions can enter into various government agencies and can carry out proselytizing to the government openly.

In addition, the idea of the birth of the Recitation and Recitation of Tasawuf, Tawheed and Jurisprudence (TASTAFI) initiated by its formation by Têungku Hasanoel Bashry, is another proof of the da'wah movement which he developed. Moreover, the TASTAFI assembly is already a legal entity and has developed quickly among the people of Aceh, even outside of Aceh such as Medan and Malaysia.

Da'wah media used by Têungkū Hasanoel Bashry are not only limited to the sermon's pulpit as is usual, but the da'wah movement has begun to keep abreast of the times using the advances in information technology. Today, Têungkū Hasanoel Bashry has been preaching through Mass Media such as through Print Media, Online Media, and Electronic Media. Tabloid Umdah (published by LBM MUDI) is one of the means of Têungku Hasanoel Bashry to do da'wah through print media. Then in online media, it can be seen from its activeness in da'wah through Facebook with Abu Mudi's account, and the spread of da'wah uploaded on Youtube. In addition, Têungkū Hasanoel Bashry also actively fills several da'wah programs on several local radios, which incidentally are Electronic Media.

\section{Research Method}

This research is a qualitative research using descriptive-analytical research that aims to provide answers to problems in the field of da'wah and identify problems or check conditions and practices that apply. Data collected in qualitative research on character studies include observational data, interviews, documentation and notes on the character's life journey.

The data obtained were then analyzed using descriptive qualitative analysis methods, the analysis process carried out in conjunction with research. The author analyzes the data through three stages namely, reducing data, displaying data and drawing conclusions/verification descriptively.

\section{Result and Discussion}

\subsection{The Da'wah Movement of Tūngkū Hasanoel Bashry a. Da'wah Movement}

Têungkū Hasanoel Bashry carried out the da'wah movements in several forms which he applied in carrying out his da'wah, including:

1. Field of education

a) Formal Education

The formal education developed by Têungkū Hasanoel Bashry all this time, namely Junior High School (SMP) and Vocational High School (SMK) which is placed in the Dayah Jamiah Al-Aziziyah complex, Batee Iliek Village, Samalanga District, Dayah Jamiah is one of the branches of Dayah MUDI Mesjid Raya Samalanga which was established in 2012. Furthermore, the Al-Aziziyah Islamic Institute (IAI) was once the Al-Aziziyah Islamic High School (STAI) which was established in 2003, which until 
now has 3 (three) faculties and 8 study programs and has graduated more than 2000 graduates up to in 2017.

b) Non-Formal Education

Non-Formal Education developed at the MUDI Islamic Boarding School in Mesjid Raya is Package B and Package $C$ which is opened specifically for students who do not have a Junior High School (SMP) and Senior High School (SMA), this Package B and $\mathrm{C}$ education collaborates with the Department Education and Culture Bireuen Regency at the time through the Intercession of the Head of the Regional Technical Implementation Unit (UPTD) Samalanga District. Furthermore Madrasah Aliyah Dayah MUDI Mesjid Raya Samalanga, where students who have completed their Education at the Aliyah Level will be awarded the Aliyah dayah diploma. In addition there is also a Higher Education or called Ma'had Aly, which in 2017 was inaugurated by the Minister of Religion of the Republic of Indonesia, MUDI Dayah Mesjid Raya is one of the dayahs given the confidence to develop Ma'had Aly Education.

c) Taklim Assembly

Têungkū Hasanoel Bashry until now takes care of several majelis taklim, such as routine recitation to teachers at the MUDI Dayah of the Samalanga Grand Mosque in the dayah Complex, Recitation of the Mukim Imum and the Gampong Imum at the AlBakri Samalanga Hall every Wednesday, recitation to Officials in the Samalanga Grand Mosque in the dayah Complex, Recitation to the Mukim Imum and the Imamp Gampong at the Balai Al-Bakri Samalanga every Wednesday Bireuen Regency every Friday at the beginning of the month at the Great Mosque of Bireuen Regency, recitation of Tasauf Tauhid and Fiqh on every Friday at the beginning of the month at the Baiturrahman Mosque in Banda Aceh, and several other places.

Until now, the recitation of the Tastafi and recitation has been favored by some people, because the study was taken care of by a number of major scholars in Aceh. The Tastafi Management has also been formed in several regencies / cities and apart from being an organization, Tastafi also requires its management to make various studies on problems that arise in the community.

\section{Economics}

In addition to the movement in the field of Education, Têungku Hasanoel Bashry also developed a da'wah movement in the economic field by establishing the Al-Barkah Cooperative in the MUDI Mesra Dayah Complex in 1980, now the cooperative has developed rapidly, in addition to meeting all the needs of students also opened for the general public, so that it can be utilized by the community around the MUDI Dayah. In addition to cooperatives in the MUDI Dayah complex, economic development was also opened in the City of Samalanga by opening the Book of Books and Books "Bina Ilmu", ATK and Fotocoy "Toko MUDI Jaya," Al-Barkah Train Workshop "located on Jln Medan" - Banda Aceh Simpang Matang Samalanga, the "MUDI Mekar" Convenience Store in Keude Ulee Gle, "Yadara" Mineral Water Distributor, Swallow Bird's Nest and providing cookware and cosmos for students and the MUDI Dayah teacher board at Mesjid Raya with an annual and monthly rental system. From the results of these efforts, the benefits will be divided annually between the MUDI Dayah Mesjid Raya and the manager, most of the business managers will be the teacher council that still lives in the MUDI Mesjid Raya Dayah complex in order to help their economy. 
3. The Social Sector

In addition to Education and Economics, the Da'wah movement Têungkū Hasanoel Bashry also formed the MUDI Mesra Alumni Association since 2000, in which every Mbahasah event will be held in all dayah scholars in the MUDI Mesra Samalanga Dayah Complex with a book review system in solving problems faced by the community both related to religious law and other laws. MUDI Mesjid Raya alumni association is very kuta and has been formed in every district / city and its management has been established every 5 (five) years.

\section{Politics}

In developing the Da'wah movement in addition to Education, economic and social channels, in the political sphere also Têungkū Hasanoel Bashry was directly involved in giving birth to the Aceh Daulat Party, (now the Aceh Regional Party), in giving birth to the party Têungkū Hasanoel Bashry in collaboration with several other Acehnese ulema. so that in the structure of the Aceh Daulat Party, formerly Têungkū Hasanoel Bashry served as the party coach. The reason Têungkū Hasanoel Bashry was involved in giving birth to political parties was that dayah graduates were able to enter the government or as policy makers in advancing education in the religious field. In a number of elections for the Regent and Deputy Regent of Bireuen, the Governor and Deputy Governor of Aceh, Têungkū Hasanoel Bashry also participated in the campaign of one of the candidates and participated in the siege as well, it became one of the evidences that Têungku Hasanoel Bashry indeed had his own views in politics.

\section{Government Sector}

In the field of government, Têungkū Hasanoel Bashry is one of the ulemas entrusted by the government as an advisor to the government in the religious field, so that the relationship between ulema and umara goes well. Têungkū Hasanoel Bashry was also entrusted by other Acehnese ulemas to lead the Aceh Ulama Daya Association (HUDA) organization as chair of the 2015-2020 terms. HUDA organization is an organization that can deal directly with the government and remind the government if it violates the rules in the religious field.

In addition, Têungkū Hasanoel Bashry was entrusted as an advisor to the Aceh Province Ulama Consultative Council (MPU) for the 2017-2022 term, with this position certainly Têungku Hasanoel Bashry could provide good input and advice to the Aceh MPU institution and remind Aceh Chairmen and MPU Members if the wrong in taking policy or not in accordance with applicable rules.

\section{b. Da'wah Media}

In carrying out the da'wah movement, of course, requires the media to support the activities of the da'wah movement. Têungkū Hasanoel Bashry in carrying out his da'wah activities was also supported by several media that supported his activities, including the following:

1. College

In 2003, Têungkū Hasanoel Bashry, full of courage and determination, made a new breakthrough in Aceh's traditional dayah environment. The breakthrough is to establish the Islamic High School (STAI) Al-Aziziyah in the MUDI Dayah complex of the Samalanga Grand Mosque, under the auspices of the Al-Aziziyah Islamic Education Foundation (YPIA). Although at the beginning its establishment was colored by the pros and cons of various groups, but now the Al-Aziziyah Islamic Institute (IAI) - a change of status from STAI Al- 
Aziziyah - is one of the Islamic Universities favored by the wider community.

The main objective of Têungkū Hasanoel Bashry by establishing this tertiary institution in a traditional dayah environment is purely to educate the children of the nation and to correlate between academic abilities with the ability of religious knowledge absorbed in the dayah. Besides also opening up opportunities for the middle to lower economic community in order to continue their education in college. In the period since its establishment in 2003, IAI Al-Aziziyah has enrolled 2026 graduates. This means that IAI AlAziziyah graduates have their own advantages, namely a combination of the academic side and the religious science side.

It is these graduates of IAI Al-Aziziyah who will be expected by Têungkū Hasanoel Bashry to color in various lines and aspects of people's lives. For example they can oversee and correct the practice of marriage in KUA in accordance with the provisions of religious shari'ah for those who work in KUA; can transform the understanding of true religion in accordance with the schools that we profess, if they take the profession as a teacher or lecturer.

\section{Pulpit}

Têungkū Hasanoel Bashry's da'wah activities are inseparable from the pulpit. Formerly Têungkū Hasanoel Bashry was a preacher who came down to various regions to preach. The reason Têungkū Hasanoel Bashry chose the pulpit as da'wah media in the early stages of his da'wah activity was because he followed the culture and development of da'wah in society. Where the pulpit is synonymous with preaching activities in preaching. But along with its development and sensitivity to the output of its da'wah activities, the pulpit has no longer been used as its da'wah media in recent years. Because the assumption to change people by preaching is momentary. Changing people more quickly with recitation activities or taklim assemblies, because it is more pervasive in their souls.

\section{Mosque/Mushalla}

In addition to the pulpit which is used as a da'wah media, Têungkū Hasanoel Bashry also uses a mosque or mushalla as a medium for da'wah, because it exemplifies the same as the Messenger of Allah used to do da'wah in the mosque. The mosque which is used as a da'wah media is a mosque that has permission from the management and the government, and is not done at the time of prayer, so that it is not against the law. The reason Têungku Hasanoel Bashry chose the Mosque / Mushalla as a media for da'wah, in addition to following in the footsteps of the Messenger of Allah, the Mosque / Mushalla was a gathering place for Muslims so that it was appropriate and appropriate to be used as a media for da'wah.

4. Mass media

a) Print Media

(1) Newspaper

Print media is also one of the media in conducting da'wah activities. Especially in Aceh now there are several print media that are ready to accommodate a variety of religious thoughts and issues. This development became a great opportunity for preachers to develop da'wah activities by utilizing print media as da'wah media. That opportunity is used by Têungkū Hasanoel Bashry in developing his da'wah activities, where Têungkū Hasanoel Bashry once sent several writings on law in Serambi Indonesia daily and Waspada daily. Seeing the current phenomenon, newspapers (newspapers) can almost be said to have turned into the basic needs of society, where everyone consumes 
news every day from newspapers. Then this phenomenon is the reason Têungku Hasanoel Bashry made the newspaper as a medium in his preaching.

(2) Bulletin

Besides newspapers, another print media used by Têungkū Hasanoel Bashry for da'wah activities is the Global News Dayah Bulletin published by the Bireuen Regency Dayah Board. Where the bulletin is published quarterly (quarterly), and contains profiles of dayahs and thoughts from dayah leaders in the Bireuen Regency. The Bireuen Regency Dayah Agency has been actively publishing bulletins for the past three years, from 2014 until now. The reason for making the bulletin as a media da'wah is also almost the same as the newspaper too. In addition, the factor of necessity is also a separate reason. Because the bulletin is a Bireuen Regency Dayah Agency program, as part of the large family of dayahs, they must actively participate in running and succeeding the Dayah Agency's program.

\section{(3) Magazines}

Dayah Ma'hadal 'Ulum Diniyyah Islamiyyah (MUDI) Mesal Raya Samalanga since 2010 has been actively managing a magazine called UMDAH Magazine. The magazine is published monthly, and in each edition always contains the material of Têungkū Hasanoel Bashry's da'wah about various religious issues that occur in society. The magazine is managed by Lajnah Bahsul Masail (LBM) MUDI Dayah Mesjid Raya Samalanga. The basic purpose of the publication of the UMDAH Magazine is to transform its thoughts and knowledge to dayah students and the wider community, who have no time to absorb knowledge directly (face to face) from themselves. In addition, it is also to facilitate the ordinary people in consuming the thoughts of the previous scholars in an easily understood editor. That is the reason for Têungku Hasanoel Bashry, to make magazines as a media for da'wah.

b). Social Media

\section{(1) Facebook}

Fanpage Faceebook with the account owned by Têungkū Hasanoel Bashry. Through this fanpage account, Têungkū Hasanoel Bashry actively answers questions that are asked by everyone about religious matters, and this fanpage has become an alternative for Facebook users to ask religious questions and other issues directly to Têungkū Hasanoel Bashry.

\section{(2) Twitter}

In addition to the facebook fanpage, Têungkū Hasanoel Bashry also uses Twitter with the LBM MUDI Mesra LBM account as an official account in presenting laws or answering issues asked by this Twitter user. The reason for using Twitter as a da'wah media is a request from the Taklim Assembly participants, because there are some people who don't like to use Facebook or other social media. The reason Têungku Hasanoel Bashry made social media (Facebook and Twitter) his preaching media was because he saw the development of social media which is increasingly mushrooming in society. So that social media is considered effective to be used as da'wah media because it is not limited in space and time, and can be absorbed by all walks of life. That is the reason for active preaching on social media. Besides also utilizing the advancement of information technology in terms of good and beneficial, which is transforming his preaching thoughts to the wider community. 


\section{c. The Da'wah Method}

In their preaching movements or activities so far, Têungkū Hasanoel Bashry applies several methods that are almost the same as those applied by other preachers. The methods of Da'wah Têungkū Hasanoel Bashry's methods are as follows:

1. Lecture method

Da'wah and lectures are two inseparable things. All preachers in conducting da'wah activities in general with the lecture method, in addition to also using other methods. Likewise, Têungkū Hasanoel Bashry, the lecture method or often called tausyiah is also of ten applied in carrying out its da'wah activities. This method is often used when preaching at certain moments in the context of celebrating Islamic holidays. Such as commemoration of the Hijri New Year, Mawlid and Ramadan lectures, which are conducted in the environment of Educational Institutions, the Government and other institutions that invited him. In recent years, there have been several foreign institutions that invited him to provide religious Tausyiah, such as Brunei Darussalam, Malaysia and Singapore.

\section{Question and answer method}

Lately, Têungkū Hasanoel Bashry prefers the question and answer method as one of the da'wah methods in addition to the other methods. This was done by Têungkū Hasanoel Bashry at Dayah Bustanul Ma'arif Kota Langsa. At that time, due to Têungkū Hasanoel Bashry's condition being unwell and unable to give a speech, Têungkū Hasanoel Bashry had worked on this by giving the audience an opportunity to ask about anything related to religious matters. At first the madu were not brave enough to ask directly, maybe hesitate or a variety of other reasons. Seeing the madness of the mad'u, Têungkū Hasanoel Bashry maneuvered it by opening a question and answer service via Shot Massage Service (SMS) to Têungkū Hasanoel Bashry's cellphone number which was immediately given to mad'u. Then Têungkū Hasanoel Bashry answers every question from madame that is asked via SMS. It turned out that the question and answer service via SMS was effective and received an overwhelming response from you. This is indicated by the number of incoming SMS, and there are even some questions that were not answered at the time. Since then, the da'wah through the Question and Answer method via SMS has continued to this day. not only in Langsa City, but in all regions in Aceh. So finally Têungkū Hasanoel Bashry argues that da'wah methods like this are more useful and effective compared to other methods, if da'wah itself is carried out in front of the crowd. Because madu will be more free and straightforward to ask via SMS, even if the question is personal. Moreover, Têungkū Hasanoel Bashry never mentioned the identity of the person who asked. In addition to serving questions and answers via SMS, Têungkū Hasanoel Bashry also developed this question and answer method by utilizing information technology advancements. Where Têungkū Hasanoel Bashry also serves questions and answers about religious issues via Facebook, WhatsApp and Twitter.

\section{Discussion Method}

On certain occasions, Têungkū Hasanoel Bashry applies the method of discussion in his da'wah activities. This means that the method of discussion is devoted to the use of conditions that are more formal in nature, and aims to give birth to a decision of the preacher regarding the problems of the Ulema. Têungku Hasanoel Bashry applies the method of discussion in the activities of Muzakarah Ulama, organized by the Government and organized by Islamic Education Institutions.

\section{Consultation Method}

Têungkū Hasanoel Bashry often practices the consultation method when one or two of the madu want to get further explanation related to the personal problem of the madu. 
Generally, the mad'u goes to Têungku Hasanoel Bashry directly at his residence or in his private office to consult the religious problems faced by the mad'u. Da'wah activities with this consultation method are practiced almost daily by Têungkū Hasanoel Bashry.

\section{Demonstration Method}

The demonstration method that had been used as a da'wah method by Têungkū Hasanoel Bashry was more specific to the pilgrims in Bireuen Regency. In his da'wah activities, Têungku Hasanoel Bashry directs and practices the procedures for performing the Hajj and Umrah pilgrimage. Even now there are already a number of Hajj and Umrah travel services that use the services of Têungkū Hasanoel Bashry as pilgrim guides, such as El-Hanif Travel, An-Nawiyah and Yadara Travel.

\section{Religious Education and Teaching Council}

Têungkū Hasanoel Bashry in carrying out his da'wah uses many educational assemblies as a da'wah method. Because according to Têungkū Hasanoel Bashry, preaching through education / recitation is more beneficial than preaching through lectures. In recent years there have been many educational assemblies (majlis ta'lim) who invited Têungkū Hasanoel Bashry to give weekly or monthly teaching. So that sometimes there must be represented by students who are trusted, namely Têungkū H. Helmi Imran, MA and Têungkū Tarmizi Al-Yusufi. As an additional note, Têungkū Hasanoel Bashry was the initiator and initiator of the birth of the TASTAFI Study Council (Sufism, Tawhid, and Fiqh). The TASTAFI Study Council is growing rapidly not only in Aceh, but has been held outside Aceh.

\section{d. Da'wah Location}

In carrying out the da'wah activities, Têungkū Hasanoel Bashry is still active in carrying out the da'wah routines in Aceh, such as recitation at Al-Bakri Mushalla in Samalanga District, Darul Jamil Beureunuen Mosque, Baiturrahim Lhoksukon North Aceh Regency, Agung Mosque Bireuen Regency, Kembang Tanjong Mosque, Pidie Regency, Bujang Salim Krueng Geukueh Mosque, Al-falah Mosque Sigli City, Taqarrub Mosque in North Sumatra Province, Mushalla Sirajul Mudhi Foundation, DKI Jakarta Province, and also fills Islamic studies in Kuala Lumpur, Johor Baru and Kajang The State of Malaysia initiated by Dr. Husni Turbo German alumni.

\section{e. Da'wah material}

Overall, the material of Da'wah Têungkū Hasanoel Bashry talks about the main problems of religion, namely the matter of monotheism (aqeedah), fiqh (sharia), and Sufism (morals). In delivering the material, Têungkū Hasanoel Bashry also did not close himself to contemporary problems of the people. Every preaching material conveyed certainly refers to al-Qur'an, hadith, and ijma 'of the previous scholars.

Al-Qur'an is the main source of reference for mankind in living life, while the Hadith is as a guide to real truth. Thus, whatever is conveyed (material) in the activities of Islamic proselytizing must be based on the Qur'an and the Hadith of the Prophet Muhammad. In this case, A. Hasjimy said that the da'wah material is the contents of the message or everything that must be conveyed by a preacher to the madu which includes all Islamic teachings sourced from the Qur'an and Hadith.

\section{Conclusion}

The Da'wah movement delivered by Têungkū Hasanoel Bashry is a movement that 
needs to be well appreciated, because until now Têungkū Hasanoel Bashry is still actively conducting the da'wah movement in solving various problems that arise in society today. As for the conclusions in this discussion include:

1. Têungkū Hasanoel Bashry in his da'wah movement has described various da'wah movements that he did, ranging from establishing educational institutions, developing economies, forming social organizations, undergoing cooperation with the government, and even entering the political world. The da'wah movement Têungkū Hasanoel Bashry has been able to answer a variety of problems faced by society at this time, ranging from the Aqeedah, Shari'ah, and contemporary issues. The Teungku Hasanoel Hasano Bashry movement has been able to inspire the public to participate in various da'wah activities which are conveyed through discussion media, questions and answers, print media, electronic media and social media. So the da'wah that he delivered was liked by various groups of people, men and women, parents and also young people.

2. The foundation of the da'wah movement used by Teungku Hasanoel Bashry in carrying out da'wah activities always uses the arguments of the verses of the Qur'an, the Hadith, and the texts of the books written by scholars who have received recognition from previous scholars. By using arguments relevant to the demands of the times, it is increasingly strengthened that the Teungku Hasanoel Bashry da'wah movement always adheres to the propositions that have been recognized as legitimate, thus making the da'wah movements that it develops increasingly popular with the wider community.

\section{References}

A. Hasjimy, (1994). Dustur Dakwah Menurut al-Qur'an, Jakarta: Bulan Bintang.

A. Ilyaz Ismail, (2006). Paradigma Dakwah Sayyid Quthub; Rekonstruksi Pemikiran Dakwah Harakah, Jakarta: Penamadani.

Paradigma Dakwah Sayyid Quthub, Rekonstruksi Pemikiran Dakwah Harakah, 2008)Cet. II, Jakarta: Penamadani.

Abdul Kadir Munsy, (1981). Metode Diskusi Dalam Dakwah, Surabaya: Al-Ikhlas.

Abdullah bin Muhammad, (2003). Tafsir Ibnu Kasir, Juz-IV, Bandung: Sinar Baru Algensindo,

Abdullah, (2002). Wawasan Dakwah, Cet. II, Medan: IAIN Press.

Aji Damanuri, (2010) Metodologi Penelitian Mu'amalah, Ponorogo: STAIN PO PRESS.

Amrullah Ahmad, (2008 ). "Konstruksi Keilmuan Dakwah dan Pengembangan Jurusan-Konsentrasi Studi”, Makalah, Unit Fakultas Dakwah IAIN Walisongo, Semarang 19-20 Desember.

Asmuni Syukir, (1983). Dasar-dasar Strategi Dakwah Islam, Surabaya: Al-Iklas.

Basrowi dan Suwandi, (2008) Memahami Penelitian Kualitatif, Jakarta: Rineke Cipta.

Hafi Anshari,( 1993). Pemahaman dan Pengalaman Dakwab: Pedoman Untuk Mujabid Dakwah Surabaya: Al-Ikhlas.

Hasan Ibn Falah al-Qattany, (1993). al-Tariq ila al-Nabdab al-Islamiyyah, Riyad: Dar alHamidi.

Hasbi Amiruddin, (2009). Menatap Masa Depan Dayah di Aceh, Yogyakarta: Polydoor.

Ibn Manzhur, (1990). Lisan al-Arab, Cet. Ke-1, Beirut: Dar Shadir.

Ilyas Ismail dan Prio Hotman, (2011). Filsafat Dakwab: Rekayasa Membangun Agama dan Peradaban Islam, Cet. Ke-1, Jakarta: Prenada Media Group.

Jalaluddin Rakhmat, (1997). Televisi sudah Menjadi The First God, dalam Ibrahim, Idi Subandy \& Malik, Hegemoni Budaya, Yogyakarta: Yayasan Bentang Budaya.

Keith Tester, (2003). Media, Budaya, dan Moralitas, Terj. Muhammad Syukri, (Yogyakarta: Juxtapose.

M. Hasbi Amiruddin, (2003). Ulama Dayah, Pengawal Agama Masyarakat Aceh, Lhokseumawe: Nadiya Foundation. 
M. Munir, (2006). Metode Dakwah, Edisi Revisi, Cet. II, Jakarta: Kencana

Muhammad al-Ghazali, (2005). Fi Maukib al-Da"wah, Kairo: Maktabah Nahdah al-Misr.

Muhammad Nashiruddin Al-Bani, (2005). Ringkasan Shabih Bukhari, Juz-IV, tp: Pustaka AsSunnah.

Munir dan Wahyu Ilaihi, (2006). Manajemen Dakwah, Cet. I, Jakarta: Kencana.

Noeng Muhajir, (1996). Metodologi Penelitian Kualitatif, Yogyakarta: Rake Sarakin.

Saiful Bahri, (2018). Hadiths About Communication Ethics (Study of Hadiths about Responsibility and Maintaining Information Accuracy), Budapest International Research and Critics InstituteJournal (BIRCI-Journal).

Samsul Munir Amin,( 2009) Ilmu Dakwah, Jakarta: Amzah.

Siti Muriah, (2000). Metodologi Penelitian Dakwah, Yokyakarta: Mitra Pustaka.

Syaikh Salim bin 'Ied Al-Hilali, (2005 ). Syarah Riyadhush Shalibin, Jakarta: Pustaka Imam Syafi'i. Syukur Kholil, (2007). Komunikasi Islam, Bandung: Citapustaka.

Syukur Kholil, Iskandar Zulkarnain, Saiful Bahri, (2018). The Existence of Public Relation in Constructing Image in Dayah MUDI MESRA Samalanga Bireuen, Aceh, Indonesia, IOSR Jaurnal of Humanities and Social Science ( IOSR-JHSS).

Tim Balai Pustaka Depdiknas, (2007). Kamus Besar Bahasa Indonesia, Ed. III, Cet. III, Jakarta: Balai Pustaka.

Wawancara dengan Têungkè Hasanoel Bashry, pada tanggal 20 Agustus 2015 Jam 08.00 wib. 